\title{
Atrial natriuretic peptide inhibits the actions of FSH and forskolin in meiotic maturation of pig oocytes via different signalling pathways
}

\author{
M Zhang, Y Tao, B Zhou, H Xie, F Wang, L Lei, L Huo', Q Sun' and G Xia \\ Department of Animal Physiology and Biochemistry, College of Biological Sciences, China Agricultural University, Beijing 100094, People's Republic of China \\ ${ }^{1}$ State Key Laboratory of Reproductive Biology, Institute of Zoology, Chinese Academy of Sciences, Beijing 100080, People's Republic of China
}

(Requests for offprints should be addressed to G Xia; Email: glxiachina@sohu.com)

\begin{abstract}
Atrial natriuretic peptide (ANP) as well as its receptors is found in mammalian ovary and follicular cells and its function in oocyte meiotic maturation has also been reported in Xenopus, hamster and rat. But the results are controversial and the physiological mechanism of ANP on oocyte maturation is not clear, especially the relationship between gonadotrophin and ANP as well as the signal transduction, and these need further study. The present study conducted experiments to examine these questions by using drug treatment and Western blot analysis and focused on pig oocyte meiotic maturation and cumulus expansion in vitro. The results revealed that ANP could inhibited FSH-induced pig oocyte maturation and cumulus expansion and prevent the full phosphorylation of mitogen-activated protein kinase in both oocytes and cumulus cells, and that these inhibitory effects could be mimicked by 8-Br-cyclic guanosine 5'-monophosphate (8-Br-cGMP), but blocked by a protein kinase G (PKG) inhibitor KT5823. Zaprinast, a cGMP-specific phosphodiesterase inhibitor, could enhance the inhibitory effect of ANP on oocyte maturation. A specific analogue of ANP, C-ANP-(4-23), which binds to the natriuretic peptide receptor-C (NPRC), had no effect in either FSH-induced or spontaneous oocyte maturation. Treatment with forskolin, a stimulator of adenylate cyclase, had a biphasic effect; $44 \mathrm{~h}$ treatment induced cumulus expansion but inhibited oocyte maturation while $2 \mathrm{~h}$ treatment induced maturation of cumulus-enclosed oocytes (CEOs). Both ANP and C-ANP-(4-23) could inhibit the effect of forskolin on CEO maturation, and these inhibitory effects of ANP/C-ANP-(4-23) could be blocked by preincubation with pertussis toxin (PT), consistent with mediation by a Gi protein(s) in the cumulus cells. All these results suggest that ANP is a multifunctional regulator of FSH and forskolin on pig CEO maturation by two signalling mechanisms: one is via a cGMP/PKG pathway, the other is via NPRC receptors in cumulus cells and the activation of the PT-sensitive Gi protein(s).
\end{abstract}

Journal of Molecular Endocrinology (2005) 34, 459-472

\section{Introduction}

Atrial natriuretic peptide (ANP) or atrial natriuretic factor (ANF) is one of a family of hormones all sharing a common 17-amino acid ring closed by a disulphide bound between two cysteine residues and varying only in the length of their $\mathrm{N}$ - and C-terminal extensions (Flynn et al. 1983). ANP is involved in the regulation of blood pressure, salt and water excretion, cell proliferation, body fluid homeostasis (for review see De Bold et al. 1991) and the release of aldosterone, vasopressin, androgen, progesterone and growth hormone (for review see Rosenzweig \& Seidman 1991). The diverse physiological responses of ANP are manifested by binding to its specific cell-surface receptors. There are four types of natriuretic peptide receptors that have been identified by molecular cloning techniques: natriuretic peptide receptor-A (NPRA), natriuretic peptide receptor-B (NPRB), natriuretic peptide receptor-G (NPRG) and natriuretic peptide receptor-D (for review see Takei 2001). NPRA receptors exhibit high affinity for ANP and brain natriuretic peptide, and NPRB is specific to C-type natriuretic peptide (for review see Takei 2000). Both NPRA and NPRB receptors can activate particulate guanylate cyclase and stimulate cyclic guanosine 5'monophosphate (cGMP) to produce physiological responses in many tissues and cells (Pandey et al. 2000). ANP also binds with high affinity to NPRC, which has been suggested to clear ANP from the circulation (for review see Maack 1992) and to play a mediatory role in the ANP-dependent inhibitory action on adenylyl cyclase, but has no intrinsic ability to generate cGMP (Drewett et al. 1992). The 5-amino acid, ring-deleted ANP analogue, (des $\left(\mathrm{Gln}^{18} \mathrm{Ser}^{19} \mathrm{Gly}^{20} \mathrm{Leu}^{21} \mathrm{Gly}^{22}\right) \mathrm{rANF}-$ (4-23)- $\mathrm{NH}_{2}$ ), which is designated as C-ANP-(4-23), has been reported to be specific for the NPRC receptor (Maack et al. 1987, Bovy et al. 1989), even though it 
interacts with the NPRA and NPRB receptors at high (>1 mM) concentrations (Konrad et al. 1991).

It is found that ANP localizes in mammalian oviduct (Russinova et al. 2001), ovary (Steegers et al. 1990), follicular fluid (Anderson et al. 1994), granulosa cells (Ivanova et al. 2003), oocytes (Kim et al. 1993) and the corpus luteum (Vollmar et al. 1988). Because of a local production, ANP may also act as an autocrine and/or paracrine hormone that influences the function of many tissues including ovarian growth or steroidogenesis (Gutkowska et al. 1993), regulation of follicular fluid dynamics (Kim et al. 1992, Gutkowska et al. 1999), oviductal motility (Kim et al. 1997), and communication within the female reproductive tract (Usuki et al. 1993, Gerbes et al. 1994). NPRA receptor has been found in human and bovine ovary (Kim et al. 1987, Saheki et al. 1989) and the receptor numbers increase with follicular cell growth (Kim et al. 1987). This finding, together with the findings that the ovary appears to be a site of ANP synthesis (Vollmar et al. 1988, Johnson et al. 1994), suggests that in the ovaries the locally synthesized ANP may act as a functional natriuretic peptide to produce physiological responses.

The actions of gonadotrophins on ovarian functions are believed to be mediated in large part through increased production of the second messenger adenosine 3',5'-cyclic monophosphate (cAMP), and subsequent activation of specific signalling pathways involving phosphorylation of mitogen-activated protein kinase (MAPK) (Eppig 1993, Fan et al. 2003). Recent studies indicate that the second messenger cGMP also mediates a wide range of influences on the function of the ovary (for review see La Polt et al. 2002). ANP can affect oocyte maturation by cGMP, i.e. ANP participates in ovum development by stimulation of cGMP accumulation and activation of cAMP-phosphodiesterase, and thereby promotes Xenopus ovum maturation (Sandberg et al. 1993) and resumption of meiosis in hamster oocytes (Hubbard \& Price 1988). On the other hand, ANP dose-dependently inhibits spontaneous maturation of rat oocytes via cGMP accumulation (Törnell et al. 1990). We have also shown that ANP inhibits folliclestimulating hormone (FSH)-induced pig cumulusenclosed oocyte (CEO) maturation in a dose-dependent manner (M Zhang, Y Tao, G Xia, H Xie, H Hong, F Wang \& L Lei, unpublished observations). These varied results suggest that there may be different signalling pathways participating in the ANP-mediated action on mammalian oocyte meiotic maturation.

Forskolin, a stimulator of adenylate cyclase (Homa 1988, Sirard 1990) which increases cAMP levels in both CEOs and denuded oocytes (DOs) (Olsiewski \& Beer 1983, Dekel et al. 1984), has been used in several studies to investigate the role of cAMP in the regulation of meiotic maturation in mammalian oocytes (Racowsky 1985, Xia et al. 1994, 2000). Forskolin mimics the effects of FSH by the stimulation of cAMP synthesis and cAMP-dependent protein kinase A (PKA) activation (Cameron et al. 1996), induces cumulus mass expansion (Racowsky 1985), and inhibits or promotes oocyte maturation after treatment for different times (Xia et al. 2000, Lu et al. 2001). It has been reported that ANP significantly reduces forskolin-stimulated cAMP accumulation via NPRC receptors and reduction of ligandstimulated adenylyl cyclase activity in rat alveolar epithelial type 2 cells (Panchenko et al. 1998) and in guinea pig airway smooth muscle (Devillier et al. 2001). All these reported mechanisms of ANP participation in other tissues or cells are not clarified in oocyte development and maturation.

The aim of this study was to examine whether ANP could influence the actions of FSH and forskolin on meiotic maturation of pig oocytes in vitro and, in that case, by which mechanism, since ANP has been found in granulosa cells of the pig ovarian follicle (Kim et al. 1992, Ivanova et al. 2003).

\section{Materials and methods}

\section{Chemicals}

The synthetic human ANP-(1-28) and $\operatorname{des}\left(\mathrm{Gln}^{18}\right.$ Ser ${ }^{19} \mathrm{Gly}^{20} \mathrm{Leu}^{21} \mathrm{Gly}^{22}$ )rANF-(4-23)-NH 2 (C-ANP-(4-23)) were prepared as $0.1 \mathrm{mM}$ stock solutions. 8-Br-cGMP was prepared as a $0.1 \mathrm{M}$ stock solution. 2-(2propyloxyphenyl)-8-azapurin-6-one (zaprinast) and forskolin were prepared as $20 \mathrm{mM}$ stock solutions in dimethylsulphoxide and KT5823 as a $1 \mathrm{mM}$ stock solution in ethyl acetate. All chemicals were purchased from Sigma unless otherwise indicated. Human ANP was used in our study, since the whole hormone sequences of ANP are conserved within mammals (Takei 2001).

\section{Collection of pig CEOs and DOs}

Ovaries were collected from gilts at a local slaughterhouse and transported to the laboratory within $3 \mathrm{~h}$. GEOs were aspirated from follicles of $3-6 \mathrm{~mm}$ in diameter in Tyrode's lactate-Hepes medium with polyvinyl alcohol (Tatemoto et al. 2001). Pig follicular fluid was harvested at the same time, and was centrifuged at $1000 \mathrm{~g}$ at $4{ }^{\circ} \mathrm{C}$ for $15 \mathrm{~min}$. The supernatant fluid was collected, supplemented with $100 \mathrm{IU} / \mathrm{ml}$ penicillin $\mathrm{G}$ potassium (Sigma) and $25 \mu \mathrm{g} / \mathrm{ml}$ streptomycin sulphate (Sigma), sterilized by a $0.22 \mu \mathrm{m}$ filter and stored at $-20{ }^{\circ} \mathrm{C}$ until use. Only oocytes with a uniform ooplasm and a compact cumulus cell mass were selected for maturation culture. DOs were obtained by removing the cumulus cells with $0 \cdot 1 \%(\mathrm{w} / \mathrm{v})$ hyaluronidase. 


\section{In vitro maturation of pig oocytes}

Collected CEOs or DOs were cultured in modified NCSU-37 solution (Funahashi et al. 1994) containing $10 \%$ porcine follicular fluid $(\mathrm{v} / \mathrm{v}), 1.0 \mathrm{mM}$ glutamine, $0.6 \mathrm{mM}$ L-cysteine, $100 \mathrm{IU} / \mathrm{ml}$ penicillin $\mathrm{G}$ potassium and $50 \mu \mathrm{g} / \mathrm{ml}$ streptomycin sulphate. This medium is termed maturation medium. Groups of 50 oocytes were transferred into individual wells of a four-well Nunclon dish with $0.5 \mathrm{ml}$ maturation medium containing different drugs. The maturation medium was equilibrated overnight before culture. The culture was carried out at $39^{\circ} \mathrm{C}$ in an atmosphere with $5 \% \mathrm{CO}_{2}$ in air for $44 \mathrm{~h}$.

\section{Evaluation of oocyte maturation and cumulus expansion}

Oocytes were denuded mechanically by repeated pipetting to remove cumulus cells at the end of the culture period. The oocytes were mounted on glass slides after rinsing with saline, fixed in acetic alcohol (acetic acid:alcohol, 1:3, v/v) for $48 \mathrm{~h}$, stained with $1 \%$ acetic-orcein for 5-10 min and examined by phasecontrast microscopy (Leica, Germany) to reveal the stage of meiosis. Oocytes were assessed for maturation scoring for germinal vesicles (GVs) (meiotic arrestment), GV breakdown (GVBD) (meiotic resumption) and for the first polar body (PB1) (the first meiotic maturation).

The cumulus expansion was observed under a phase-contrast microscope. The degree of expansion was scored according to Downs (1989) and Vanderhyden (1993) from 0 to 4 grades. Briefly, no response was scored as 0 , minimum observable response was scored as 1, expansion of outer layers was scored as 2, expansion of all layers except the corona radiata was scored as 3 and expansion of all layers was scored as 4 . A cumulus expansion index (CEI) was calculated (range, $0-4 \cdot 00$ ) as described in detail previously (Fagbohun \& Downs 1990).

\section{SDS-PAGE and Western blot analysis}

For detection of active ERK1/2, proteins from 50 oocytes or cumulus cells of 50 CEOs were extracted using $2 \times$ SDS sample buffer during the different culture times and heated to $100{ }^{\circ} \mathrm{C}$ for $4 \mathrm{~min}$. After cooling on ice and centrifuging at $12000 \mathrm{~g}$ for $4 \mathrm{~min}$, samples were frozen at $-20^{\circ} \mathrm{C}$ until use. The total proteins were separated by SDS-PAGE according to the method indicated by Fan et al. (2003); briefly, 4\% stacking gel and $10 \%$ separating gel for $20 \mathrm{~min}$ at $56 \mathrm{~V}$ and $4.5 \mathrm{~h}$ at $110 \mathrm{~V}$ respectively, and then electrophoretically transferred onto nitrocellulose membranes for $2 \mathrm{~h}$ at $200 \mathrm{~mA}$ at $4{ }^{\circ} \mathrm{C}$. The membrane was blocked overnight at $4{ }^{\circ} \mathrm{C}$ in TBST $(20 \mathrm{mM}$ Tris- $\mathrm{HCl}, 150 \mathrm{mM} \mathrm{NaCl}$ and $0.1 \%$
Tween $20 \mathrm{pH} 7.5$ ) buffer containing 5\% low-fat milk, and then incubated for $1 \mathrm{~h}$ in TBST with 1:500 mouse anti-p-ERK1/2 antibody (Santa Cruz Biotechnology, Santa Cruz, CA, USA). After three washes for $10 \mathrm{~min}$ each in TBST, the membrane was incubated for $1 \mathrm{~h}$ at $37^{\circ} \mathrm{C}$ with horseradish peroxidase (HRP)-conjugated rabbit anti-mouse immunoglobulin $\mathrm{G}$ (IgG) diluted $1: 1000$ in TBST. Proteins on the membrane were visualized using an enhanced chemiluminescence (ECL) detection system (Amersham).

For reprobing total ERK2, the membrane was washed in stripping buffer $(100 \mathrm{mM} \beta$-mercaptoethanol, $20 \%$ SDS and $62.5 \mathrm{mM}$ Tris $\mathrm{pH} 6 \cdot 7$ ) to strip off bound antibody after ECL detection at $50{ }^{\circ} \mathrm{C}$ for $30 \mathrm{~min}$. The membrane was reprobed with polyclonal rabbit antiERK2 antibody (Santa Cruz Biotechnology) diluted 1:300, incubated with HRP-labelled goat anti-rabbit IgG diluted 1:1000, and finally processed as described above. All experiments were repeated at least three times.

\section{Experimental design}

\section{Experiment 1}

To study the possible effect of ANP on pig oocyte maturation, CEOs isolated from follicles were cultured in maturation medium with or without FSH $(0.05$ $\mathrm{U} / \mathrm{ml}$ ), supplemented with $100 \mathrm{nM} \mathrm{ANP} \mathrm{(an} \mathrm{appropri-}$ ate concentration based on our previous study) or C-ANP-(4-23) for $44 \mathrm{~h}$. Then the nuclear status of the oocytes and cumulus expansion were determined.

\section{Experiment 2}

The possible signalling pathway of ANP on the effect of FSH was studied by using zaprinast (a cGMP-specific phosphodiesterase inhibitor), KT5823 (a protein kinase $\mathrm{G}$ (PKG) inhibitor) and a MAPK phosphorylation assay. 8-Br-cGMP was also used to mimic the effect of ANP on oocyte maturation and MAPK phosphorylation. Pig CEOs were cultured in maturation medium containing $0.05 \mathrm{U} / \mathrm{ml}$ FSH supplemented with $100 \mathrm{nM}$ ANP, $10 \mu \mathrm{M}$ zaprinast, $1 \mu \mathrm{M}$ KT5823 and/or different dose of 8-Br-cGMP for $44 \mathrm{~h}$. Then the cumulus expansion and nuclear status of the oocytes were determined. Oocytes and cumulus cells were collected at various time intervals for Western blot analysis to investigate the effects of ANP, 8-Br-cGMP and KT5823 on MAPK phosphorylation.

\section{Experiment 3}

To investigate the relationship between ANP and cAMP on oocyte maturation, pig CEOs and DOs were cultured in FSH-free maturation medium supplemented with 


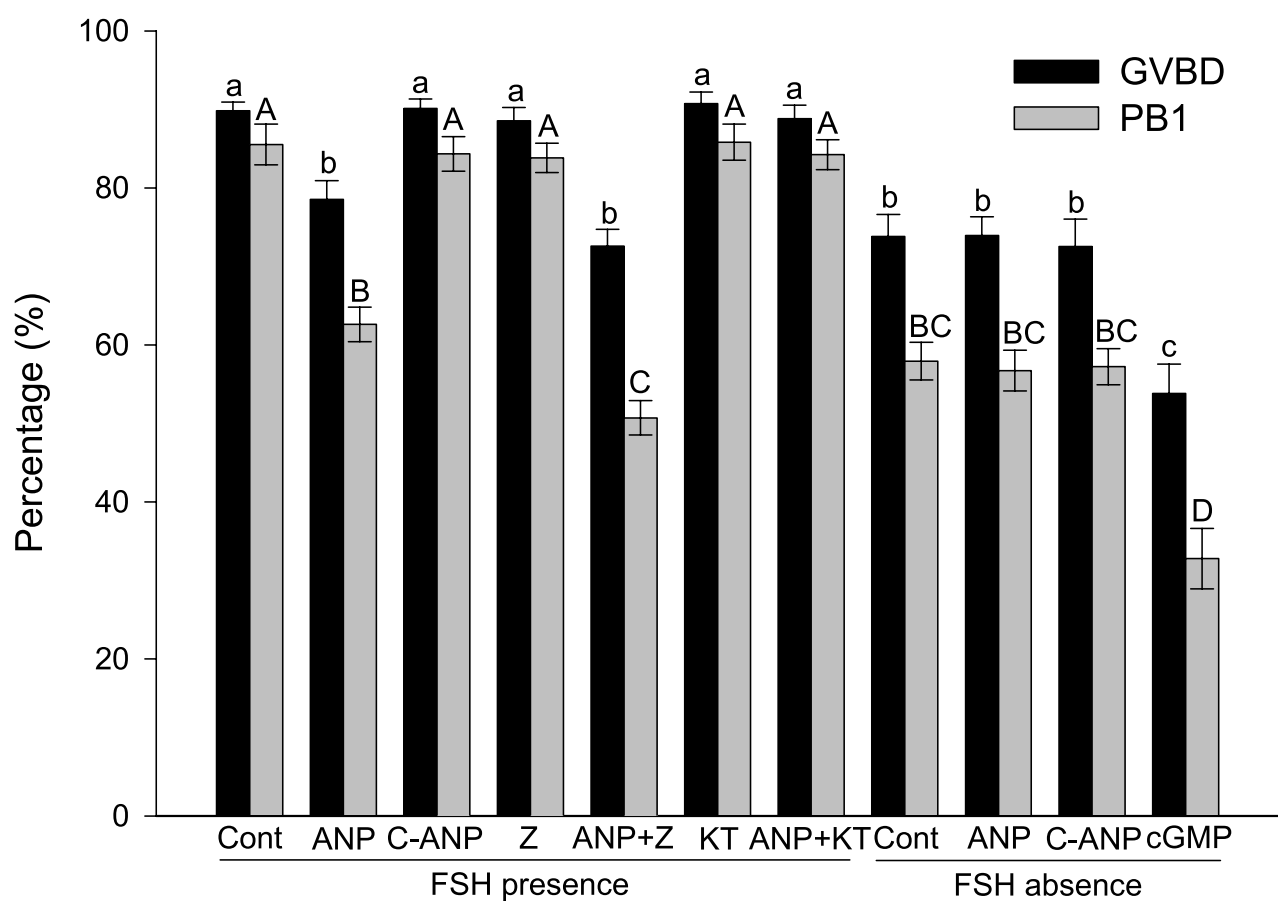

Figure 1 Effects of ANP, C-ANP-(4-23) and 8-Br-cGMP on pig oocyte maturation. Pig CEOs were cultured in NCSU-37 medium with or without FSH (0.05 U/ml), containing $100 \mathrm{nM} \mathrm{ANP,} 100 \mathrm{nM}$ C-ANP-(4-23), $0.5 \mathrm{mM}$ 8-Br-cGMP, $10 \mu \mathrm{M}$ zaprinast and/or $1 \mu \mathrm{M}$ KT5823 for $44 \mathrm{~h}$. The median number of oocytes in each group was 330 . The means \pm S.E.M. have been calculated from four independent experiments. Different superscripts denote a statistical difference at a $P<0.05$ level of significance in the GVBD or PB1 respectively. In this and subsequent figures, GVBD is the total number of oocytes which showed GVBD or PB1 stage at the end of culture, and PB1 percentages were calculated as a \% of the total oocytes examined. C-ANP, C-ANP-(4-23); Z, zaprinast; KT, KT5823; cGMP, 8-Br-cGMP.

$10 \mu \mathrm{M}$ forskolin (a stimulator of adenylate cyclase) and different doses of ANP or C-ANP-(4-23) for $44 \mathrm{~h}$, or for $2 \mathrm{~h}$ and then cultured in drug-free maturation medium until $44 \mathrm{~h}$. Then the nuclear status of the oocytes and cumulus expansion were determined.

\section{Experiment 4}

The possible pathway of ANP in the effect of forskolin during pig oocyte maturation was studied by using pertussis toxin (PT) (Sigma). After pretreated with $0.5 \mu \mathrm{g} / \mathrm{ml}$ PT for $2 \mathrm{~h}$ to block Gi protein(s) activity, pig CEOs and DOs were cultured in maturation medium with $10 \mu \mathrm{M}$ forskolin, $100 \mathrm{nM}$ ANP and/or C-ANP(4-23) for another $42 \mathrm{~h}$, or for another $2 \mathrm{~h}$ followed by culture in drug-free medium until $44 \mathrm{~h}$. The nuclear status of the oocytes and cumulus expansion were determined.

\section{Statistical analysis}

Experiments were performed at least three times and the values are given as means \pm S.E.M. In the presented data on oocyte maturation $n$ refers to number of oocytes. Maturation frequencies were subjected to arcsine transformation and analysed by ANOVA followed by Duncan's multiple range tests. $P<0.05$ was considered statistically significant.

\section{Results}

\section{ANP inhibited FSH-induced pig CEO meiotic resumption and the first meiotic maturation}

ANP and C-ANP-(4-23) were used to explore the possible participation of ANP in regulating meiotic maturation of pig oocytes. As shown in Fig. 1, FSH had a significant effect on meiotic resumption $(89 \cdot 8 \%$ GVBD) and the first meiotic maturation (85.5\% PB1, $n=327)$ compared with the FSH-absent treatment (73.8\% GVBD and $57.9 \%$ PB1, $n=341 ; P<0 \cdot 01)$. While C-ANP-(4-23) had no effect on FSH-induced oocyte maturation $(90 \cdot 1 \%$ GVBD and $84 \cdot 3 \% \mathrm{~PB} 1, n=320)$, ANP significantly inhibited FSH-induced pig oocyte maturation $(78.5 \%$ GVBD and $62.6 \% \mathrm{~PB} 1, n=339)$. 


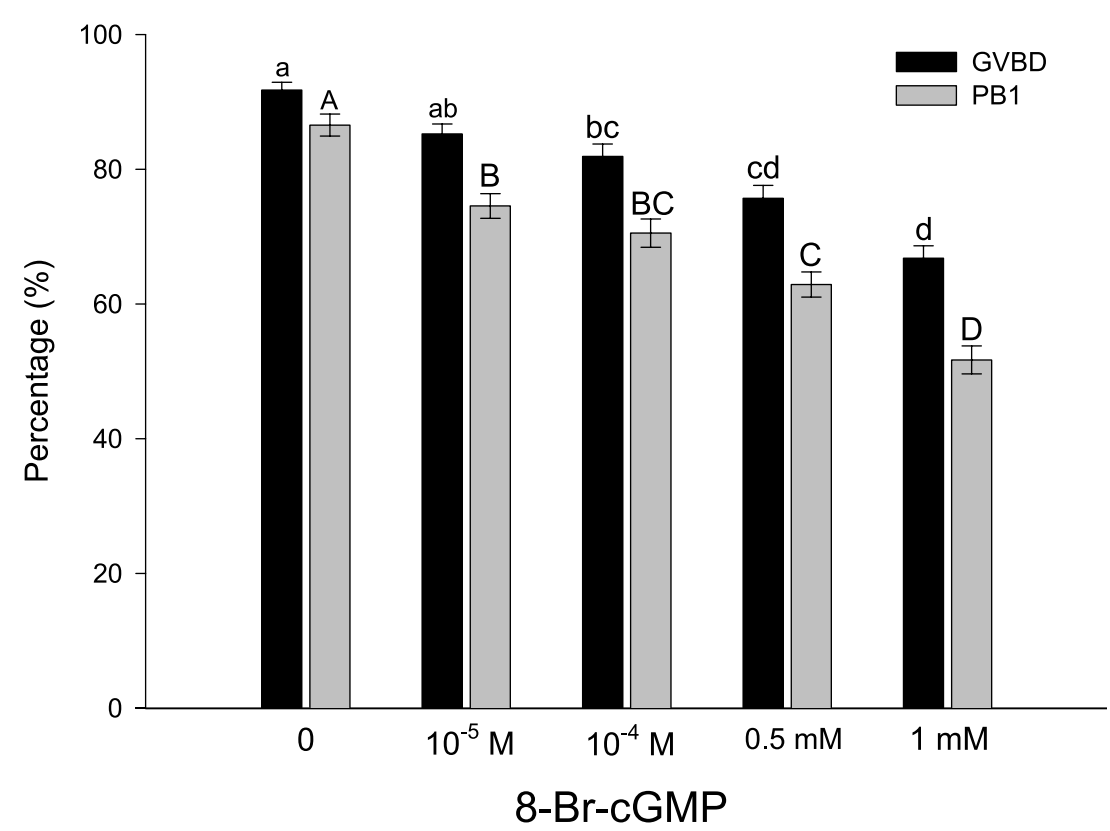

Figure 2 The effect of 8-Br-cGMP on FSH-induced pig CEO maturation. Pig CEOs were cultured in NCSU-37 maturation medium containing $0.05 \mathrm{U} / \mathrm{ml} \mathrm{FSH}$ and different doses of permeable cGMP analogue 8-Br-cGMP for $44 \mathrm{~h}$. The median number of oocytes in each group was 340 . The means \pm S.E.M. have been calculated from four experiments. Different superscripts denote statistical difference at a $P<0.05$ level of significance in the GVBD or PB1 respectively.

Both ANP and C-ANP-(4-23) were ineffective in pig CEO spontaneous maturation.

The possible mechanism of ANP on oocyte maturation was studied by using zaprinast (a cGMP-specific phosphodiesterase inhibitor), KT5823 (a specific inhibitor of cGMP-dependent protein kinase) and 8-BrcGMP. The inhibitory effect of ANP was enhanced in the presence of zaprinast $(72 \cdot 6 \%$ GVBD and $50 \cdot 7 \%$ PB1, $n=316$; Fig. 1), but completely reversed by KT5823 (88.8\% GVBD and 84.2\% PB1, $n=331)$. Zaprinast or KT5823 alone had no effect on FSH-induced pig CEO maturation (Fig. 1). 8-Br-cGMP had a similar inhibitory effect to ANP on FSH-induced oocyte maturation, and showed a dose-dependent manner in concentrations ranging from $10 \mu \mathrm{M}(85 \cdot 3 \%$ GVBD and $74 \cdot 6 \% \mathrm{~PB} 1, n=328)$ to $1 \mathrm{mM}(66 \cdot 8 \%$ GVBD and $51.7 \%$ PB1, $n=349$; Fig. 2). 8-Br-cGMP also significantly inhibited spontaneous $\mathrm{CEO}$ maturation (53.8\% GVBD and $32 \cdot 7 \%$ PB1; Fig. 1). These results revealed that the cGMP/PKG pathway is involved in this process.

\section{ANP inhibited FSH-induced MAPK phosphorylation}

The kinetics of MAPK during pig CEO maturation are shown in Fig. 3A. Phosphorylation of ERK1/2 was evaluated by a specific antibody against
phospho-MAPK. ERK1/2 existed in an inactive form in oocytes at the GV stage (Fig. 3A, lane 1). Phosphorylation of kinases was detected at $18 \mathrm{~h}$ (lane 2) and $24 \mathrm{~h}$ (lane 3) after culture. An abrupt increase was observed at MI stage oocytes (30 h of culture; lane 4), and their full phosphorylation increased in the following hours of culture and remained to the end of culture (44 h; lane 5). However, when the CEOs were cultured in maturation medium containing $100 \mathrm{nM}$ ANP (lanes 11-14) for $18,24,30$ or $44 \mathrm{~h}$, full phosphorylation of ERK1/2 was obviously inhibited.

Expression and phosphorylation of MAPK was also detected in pig cumulus cells isolated from the same 50 CEOs (Fig. 3A). Active MAPK existed in cumulus cells surrounding $\mathrm{GV}$ oocytes freshly isolated from ovaries (lane 6). A significant increase of MAPK activation was detected at $18 \mathrm{~h}$ of culture (lane 7), peaking at $24 \mathrm{~h}$ (lane 8 ) and maintained to $44 \mathrm{~h}$ (lane 10). Similarly, in cumulus cells isolated from the oocytes treated with ANP (lanes 17-20), full phosphorylation of ERK1/2 was obviously inhibited as observed by Western blotting (Fig. 3A). As shown in Fig. $3 \mathrm{~B}$ and $\mathrm{C}, 0.5 \mathrm{mM}$ 8-Br-cGMP had a similar inhibitory effect on the phosphorylation of MAPK, and KT5823 could reverse the inhibitory effect of ANP on the phosphorylation of ERK1/2 of oocytes and cumulus cells, but KT5823 alone had no effect on MAPK phosphorylation. 
A

Control
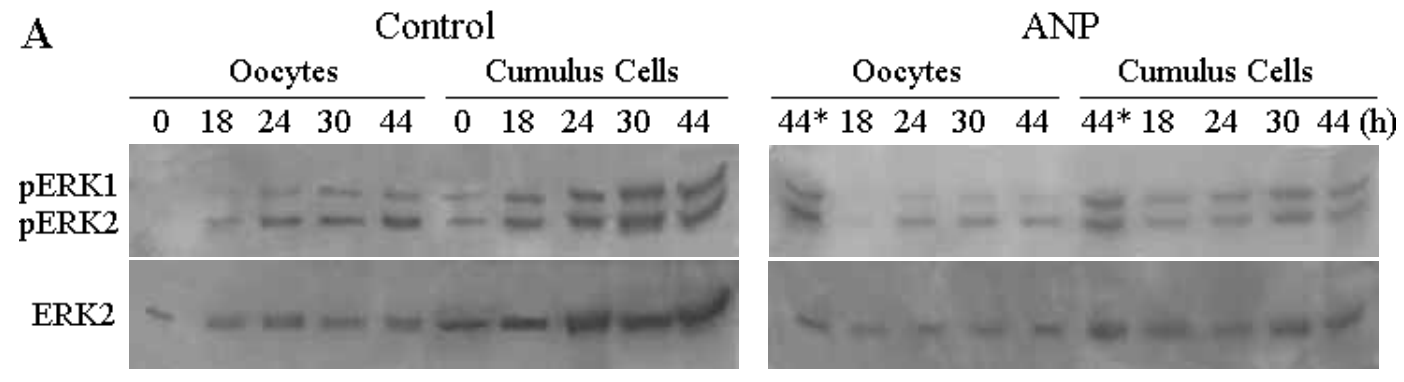

\begin{tabular}{|l|c|c|c|c|c|c|c|c|c|c|}
\hline ANP & - & + & - & - & + & - & + & - & - & + \\
\hline 8-Br-cGMP & - & - & + & - & - & - & - & + & - & - \\
\hline KT5823 & - & - & - & + & + & - & - & - & + & + \\
\hline
\end{tabular}

\section{B $\underset{\text { pERR2 }}{\text { pERK1 }}$}

ERK2

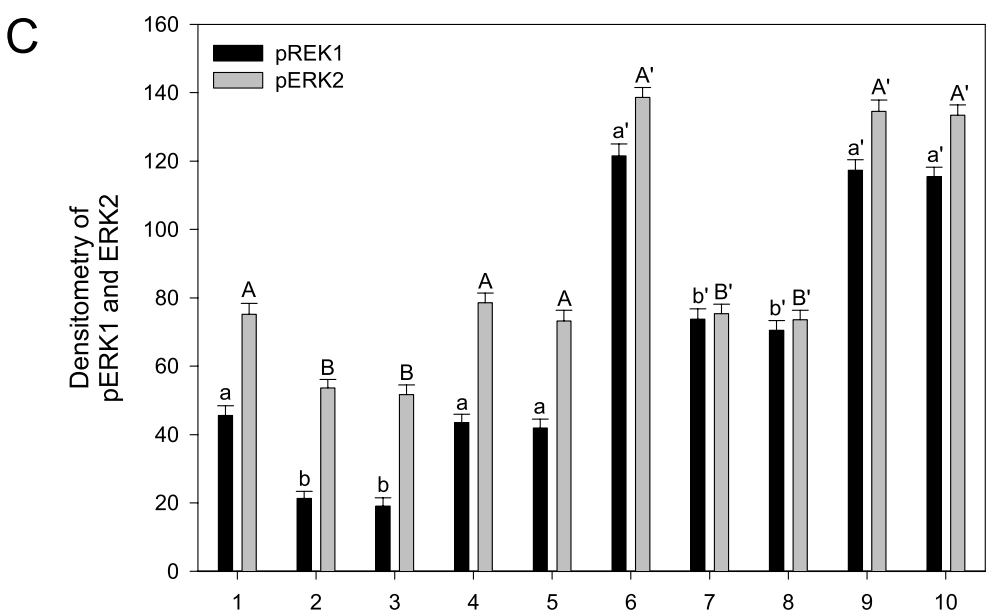

Figure 3 Effects of ANP and 8-Br-cGMP on FSH-induced ERK1/ERK2 phosphorylation in oocytes and cumulus cells. Pig CEOs were cultured for various time intervals in the maturation medium, containing $0.05 \mathrm{U} / \mathrm{ml} \mathrm{FSH}$, $100 \mathrm{nM}$ ANP, $0.5 \mathrm{mM}$ 8-Br-cGMP, and/or $10 \mu \mathrm{M}$ KT5823. ERK1/ERK2 phosphorylation in oocytes and cumulus cells was assayed as described under Materials and methods. Autoradiogram in (A and B) reflect a representative experiment and bar graphs (C) represent the mean of three independent experiments.

(A) Western blot analysis of ERK1/2 phosphorylation during oocyte maturation treated with FSH (lanes 1-10) or treated with FSH and ANP (lanes 11-20). ${ }^{*}$ KT5823 was supplemented in lanes 11 and 16 of the ANP treatment.

(B) Western blot analysis of MAPK phosphorylation during oocyte maturation treated with FSH, ANP,

8-Br-cGMP, and/or KT5823 for 44 h. Oocyte group: lanes 1-5; cumulus cell group: lanes 6-10.

(C) Quantification of total active ERK1/ERK2 in oocytes and cumulus cells. The means \pm S.E.M. have been calculated from three independent experiments. Different superscripts denote statistical difference at a $P<0.05$ level of significance in the pERK1 or pERK2 respectively. 


\section{ANP and C-ANP-(4-23) inhibited the action of forskolin on pig CEO meiotic resumption and the first meiotic maturation}

Pig CEOs were cultured in maturation medium with or without forskolin for $44 \mathrm{~h}$, and the oocyte maturation was evaluated by acetic-orcein staining. As shown in Fig. 4A, both GVBD $(73 \cdot 2 \%)$ and PB1 $(57 \cdot 0 \%, n=341)$ occurred in CEOs cultured in drug-free medium. When CEOs were treated with $10 \mu \mathrm{M}$ forskolin for $44 \mathrm{~h}$, the GVBD $(23 \cdot 8 \%)$ and PB1 $(10 \cdot 2 \%, n=363)$ were strongly inhibited. Treatment with ANP or C-ANP-(4-23) for $44 \mathrm{~h}$ dose-dependently inhibited the function of forskolin in concentrations ranging from $1 \mathrm{nM}(30 \cdot 1 \%$ GVBD and $15 \cdot 1 \%$ PB 1 with ANP treatment, $n=348 ; 33 \cdot 4 \%$ GVBD and $19 \cdot 7 \%$ PB1 with C-ANP-(4-23) treatment, $n=369)$ to $1 \mu \mathrm{M}(51 \cdot 1 \% \mathrm{GVBD}$ and $36.3 \% \mathrm{~PB} 1$ with ANP treatment, $n=371 ; 55 \cdot 3 \%$ GVBD and $37 \cdot 9 \%$ PB1 with C-ANP-(4-23) treatment, $n=355)$, although the inhibitory effect of forskolin on the meiotic resumption and the first meiotic maturation of pig CEOs was not completely reversed by even $1 \mu \mathrm{M}$ ANP or G-ANP-(4-23) (Fig. 4A).

To test the possible mechanism of ANP and C-ANP-(4-23) in regulating the action of forskolin on oocyte maturation, pig GEOs were preincubated with PT for $2 \mathrm{~h}$ to block Gi protein(s) activity, and then cultured in maturation medium containing forskolin, ANP and/or C-ANP-(4-23) for another $42 \mathrm{~h}$. As shown in Fig. 4B, the inhibitory effect of ANP and C-ANP-(4-23) on the function of forskolin was completely eliminated after treatment with PT $(25 \cdot 4 \%$ GVBD and $9 \cdot 5 \%$ PB1 with ANP treatment, $n=298$; $24 \cdot 1 \%$ GVBD and $11.9 \%$ PB1 with C-ANP-(4-23) treatment, $n=312$ ). PT alone had no effect on the function of forskolin during oocyte meiotic maturation $(23.7 \%$ GVBD and $11 \cdot 3 \%$ PB1, $n=327)$. Short-term priming with forskolin for $2 \mathrm{~h}$ could induce pig CEO maturation (89.6\% GVBD and $81.9 \%$ PB1, $n=374$; Fig. 4C). Similarly, this effect was also inhibited by ANP $(78.9 \%$ GVBD and $63.7 \%$ PB1, $n=346)$ and C-ANP-(4-23) (75.8\% GVBD and $61 \cdot 2 \%$ PB1, $n=326)$, and preincubation with PT could completely eliminate the inhibitory effect of ANP and C-ANP(4-23) on the function of forskolin short-term priming (Fig. 4C).

\section{ANP and C-ANP-(4-23) were ineffective in pig DO maturation}

The role of the cumulus cells was studied by incubating DOs with ANP, C-ANP-(4-23), and/or forskolin for $44 \mathrm{~h}$, or with forskolin for $2 \mathrm{~h}$ followed by a $42 \mathrm{~h}$ culture in drug-free medium. As shown in Fig. 5, pig oocyte maturation was strongly inhibited when DOs were treated with forskolin for $44 \mathrm{~h}(25 \cdot 6 \%$ GVBD and
$10.5 \% \mathrm{~PB} 1, n=278)$ or for $2 \mathrm{~h}(26.4 \% \mathrm{GVBD}$ and $11 \cdot 3 \% \mathrm{~PB} 1, n=284)$. ANP and C-ANP-(4-23) were ineffective in pig DO maturation cultured in drug-free medium or medium with forskolin (Fig. 5).

\section{Effect of ANP on cumulus expansion of pig CEOs}

In addition to oocyte maturation, cumulus cells were also evaluated by the CEI. As shown in Table 1 and Fig. 6, FSH induced cumulus expansion of pig CEOs to the maximal degree with a CEI of $3 \cdot 48$. ANP could significantly inhibit FSH-induced cumulus expansion (with a CEI of 2.68). This inhibitory effect of ANP could be mimicked by 8 -Br-cGMP (with a CEI of 2.64 with $0.5 \mathrm{mM}$ treatment), and was completely reversed by KT5823 (with a CEI of 3.45). The CEI was 2.19 in pig CEOs cultured in FSH-free medium, but treatment with $10 \mu \mathrm{M}$ forskolin for $44 \mathrm{~h}$, not for $2 \mathrm{~h}$, could partially induce cumulus expansion (with a CEI of 2.65). ANP was ineffective in cumulus expansion of pig CEOs cultured in drug-free medium or medium with forskolin for $44 \mathrm{~h}$.

\section{Discussion}

In the present study, we investigated the role of ANP on the effect of FSH and forskolin in pig oocyte meiotic maturation. The gonadotrophin-induced oocyte maturation, instead of spontaneous meiotic resumption, was inhibited by ANP. ANP also obviously inhibited FSH-induced ERK1/2 phosphorylation. All these inhibitory effects of ANP could be mimicked by 8-Br-cGMP but blocked by KT5823, and zaprinast enhanced the inhibitory effect of ANP on oocyte maturation. In our study, the inhibitory effect of ANP on pig oocyte maturation might be via the PKG/MAPK pathway, since FSH-induced ERK1/2 phosphorylation in both oocytes and cumulus cells is necessary for pig oocyte maturation (Fan et al. 2003). On the other hand, both ANP- and C-ANP-(4-23)-inhibited action of forskolin on CEO maturation should be via NPRC receptors and the $\mathrm{PT}$-sensitive $\mathrm{Gi}$ protein $(\mathrm{s})$, since $\mathrm{PT}$ could eliminate the inhibitory effect of ANP/C-ANP(4-23) on forskolin-induced oocyte maturation. These results are consistent with previous reports that ANP negatively regulates MAPK phosphorylation and proliferation of rat mesangial cell by the ANP/NPRA system (Pandey et al. 2000), and that ANP significantly reduces forskolin-stimulated cAMP accumulation via NPRC receptors and reduction of ligand-stimulated adenylyl cyclase activity in guinea pig airway smooth muscle (Devillier et al. 2001). While 8-Br-cGMP significantly inhibited spontaneous oocyte maturation, ANP had no effect on pig oocyte maturation in the 

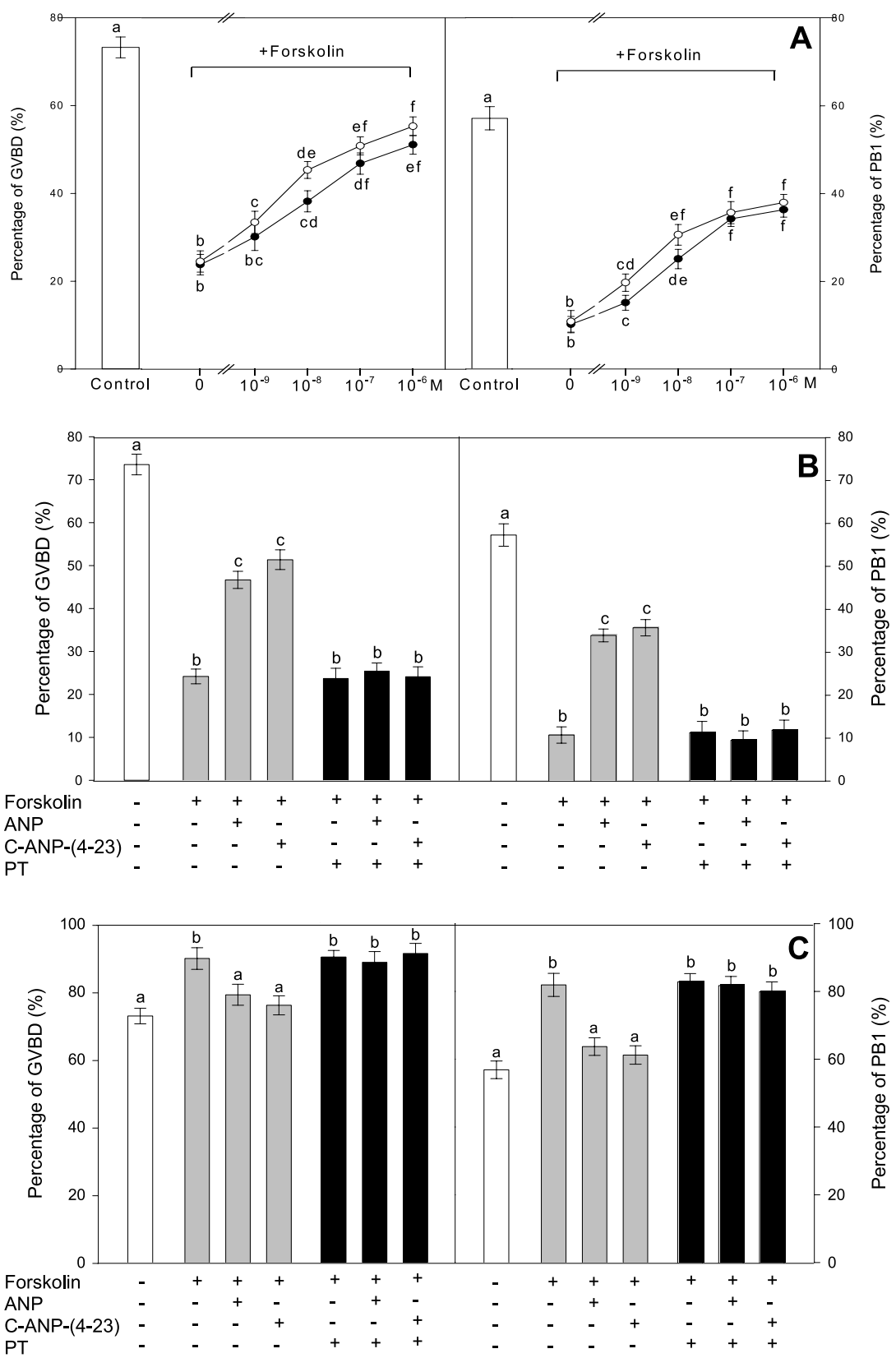

Figure 4 The effects of ANP and C-ANP-(4-23) on the action of forskolin during pig oocyte maturation. (A) Pig CEOs were culture in FSH-free medium supplemented with forskolin $(10 \mu \mathrm{M})$ and various doses of ANP $(\bullet)$ and C-ANP-(4-23) $(\bigcirc)$ for $44 \mathrm{~h}$. The median number of oocytes in each group was 340 . The means \pm S.E.M. have been calculated from four independent experiments. Different superscripts denote statistical difference at a $P<0.05$ level of significance in the GVBD or PB1 respectively. Similar demonstrations of statistical analysis are also used in the following panels. (B and $\mathrm{C}$ ) After preincubation with $0.5 \mu \mathrm{g} / \mathrm{ml}$ PT for $2 \mathrm{~h}$, pig CEOs were cultured in $10 \mu \mathrm{M}$ forskolin, $100 \mathrm{nM}$ ANP and/or C-ANP-(4-23)) for another $42 \mathrm{~h}$, or for another $2 \mathrm{~h}$ followed by culture in drug-free medium until $44 \mathrm{~h}$.

absence of FSH. The possible reason is that the receptor expression increases in the presence of the hormone (Gutkowska et al. 1999).
Previous results showed that ANP potentiates progesterone-induced Xenopus oocyte maturation by stimulation of cGMP accumulation and activation of 


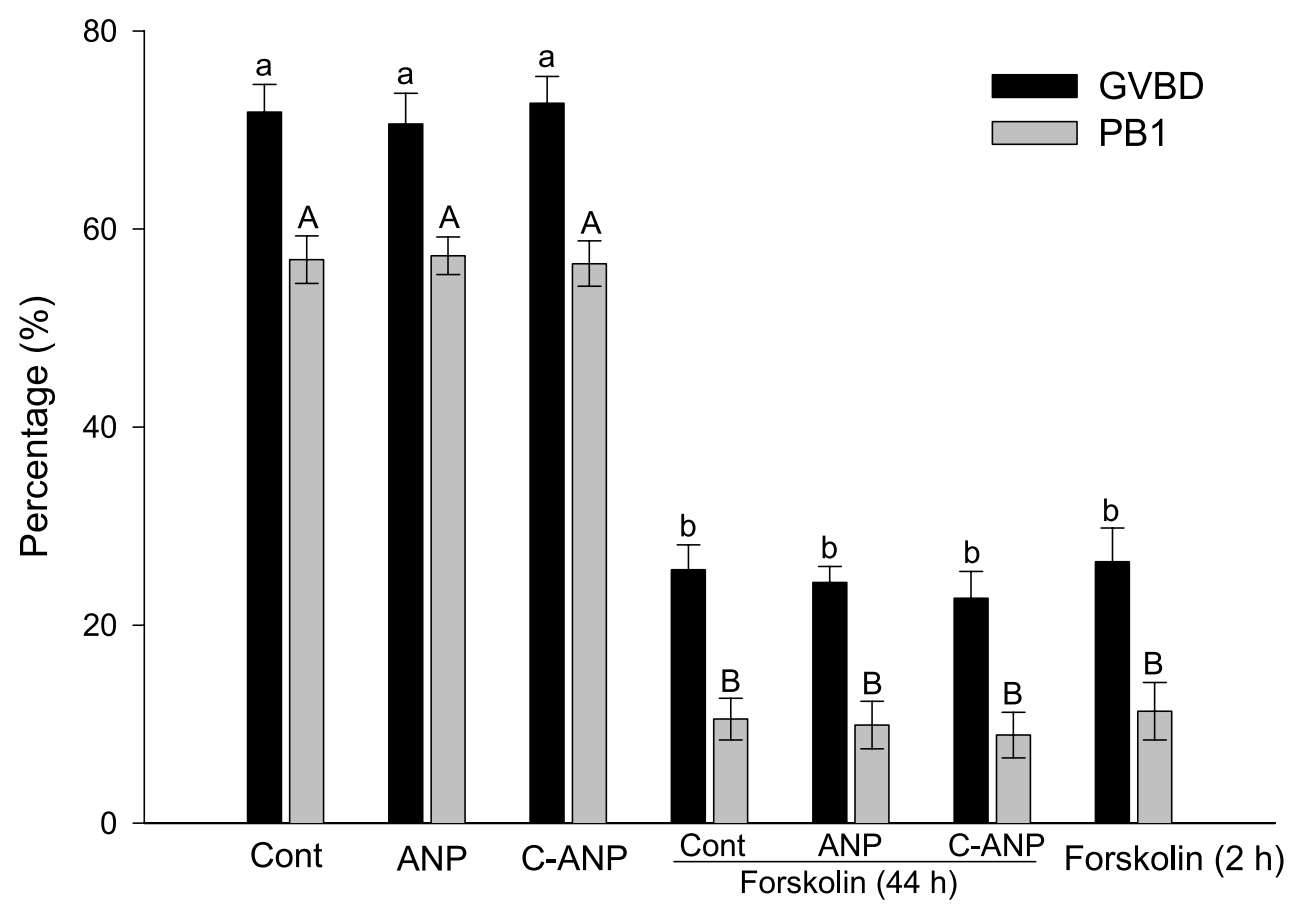

Figure 5 Effect of ANP and C-ANP-(4-23) on pig DO spontaneous maturation. Pig DOs were cultured in maturation medium with $100 \mathrm{nM}$ ANP, $100 \mathrm{nM}$ C-ANP-(4-23), and/or $10 \mu \mathrm{M}$ forskolin for $44 \mathrm{~h}$, or with $10 \mu \mathrm{M}$ forskolin for $2 \mathrm{~h}$ followed by a $42 \mathrm{~h}$ culture in drug-free medium. The median number of oocytes in each group was 300 . The means \pm S.E.M. have been calculated from four independent experiments. Different superscripts denote statistical difference at a $P<0.05$ level of significance in the GVBD or PB1 respectively. C-ANP, C-ANP-(4-23).

Table 1 Effects of ANP, C-ANP-(4-23), 8-Br-cGMP and forskolin on cumulus expansion of pig CEOs

Degree of cumulus expansion

\section{Treatment \\ FSH presence $(0.05 \mathrm{U} / \mathrm{ml})$ \\ Control \\ 100 nM ANP \\ $100 \mathrm{nM}$ C-ANP-(4-23) \\ $500 \mu \mathrm{M} 8$ 8-Br-cGMP \\ $1 \mu \mathrm{M}$ KT5823 \\ ANP +KT5823}

$\mathrm{FSH}$ absence

\section{Control}

100 nM ANP

100 nM C-ANP-(4-23)

$10 \mu \mathrm{M}$ forskolin $(44 \mathrm{~h})$

ANP+forskolin (44 h)

C-ANP-(4-23)+forskolin (44 h)

$10 \mu \mathrm{M}$ forskolin $(2 \mathrm{~h})$

\begin{tabular}{|c|c|c|c|c|c|c|}
\hline $0(\%)^{a}$ & $+1(\%)^{a}$ & $+2(\%)^{a}$ & $+3(\%)^{a}$ & $+4(\%)^{a}$ & CEI ${ }^{\mathrm{b}}$ & $n$ \\
\hline 0 & $2 \cdot 1 \pm 1 \cdot 3$ & $11 \cdot 3 \pm 4 \cdot 2$ & $22 \cdot 7 \pm 4 \cdot 1$ & $63 \cdot 9 \pm 3 \cdot 9$ & $3 \cdot 48 \pm 0 \cdot 12$ & 327 \\
\hline 0 & $16 \cdot 4 \pm 3 \cdot 3$ & $27 \cdot 1 \pm 3 \cdot 1$ & $28 \cdot 7 \pm 2 \cdot 9$ & $27 \cdot 8 \pm 3 \cdot 7$ & $2 \cdot 68 \pm 0.09^{* *}$ & 339 \\
\hline 0 & $1 \cdot 8 \pm 1 \cdot 7$ & $15 \cdot 7 \pm 4 \cdot 6$ & $22 \cdot 5 \pm 4 \cdot 9$ & $60 \cdot 0 \pm 4 \cdot 1$ & $3.41 \pm 0.13$ & 320 \\
\hline 0 & $17 \cdot 5 \pm 2 \cdot 4$ & $27 \cdot 3 \pm 3 \cdot 0$ & $28 \cdot 6 \pm 3 \cdot 3$ & $26 \cdot 6 \pm 3 \cdot 4$ & $2 \cdot 64 \pm 0 \cdot 15^{\text {** }}$ & 318 \\
\hline 0 & $2 \cdot 5 \pm 2 \cdot 3$ & $16 \cdot 5 \pm 3 \cdot 8$ & $20 \cdot 4 \pm 3 \cdot 7$ & $60 \cdot 6 \pm 3 \cdot 2$ & $3 \cdot 40 \pm 0 \cdot 10$ & 351 \\
\hline 0 & $1 \cdot 6 \pm 1.9$ & $12 \cdot 8 \pm 4 \cdot 5$ & $24 \cdot 7 \pm 3 \cdot 9$ & $60 \cdot 9 \pm 4 \cdot 2$ & $3 \cdot 45 \pm 0 \cdot 16$ & 331 \\
\hline $5 \cdot 3 \pm 2 \cdot 4$ & $23 \cdot 3 \pm 3 \cdot 2$ & $31 \cdot 5 \pm 3 \cdot 4$ & $26 \cdot 1 \pm 2 \cdot 9$ & $13 \cdot 8 \pm 3 \cdot 3$ & $2 \cdot 19 \pm 0 \cdot 15$ & 341 \\
\hline $6 \cdot 3 \pm 3 \cdot 3$ & $20 \cdot 1 \pm 2 \cdot 8$ & $32 \cdot 4 \pm 2 \cdot 7$ & $29 \cdot 7 \pm 3 \cdot 1$ & $11 \cdot 5 \pm 3.4$ & $2 \cdot 20 \pm 0 \cdot 10$ & 349 \\
\hline $5 \cdot 4 \pm 2 \cdot 5$ & $21 \cdot 5 \pm 3 \cdot 5$ & $33 \cdot 8 \pm 2 \cdot 9$ & $26 \cdot 4 \pm 2 \cdot 4$ & $12 \cdot 9 \pm 3 \cdot 1$ & $2 \cdot 20 \pm 0 \cdot 21$ & 328 \\
\hline 0 & $14 \cdot 9 \pm 2 \cdot 7$ & $29 \cdot 3 \pm 4 \cdot 1$ & $31 \cdot 9 \pm 4 \cdot 2$ & $23 \cdot 9 \pm 3 \cdot 8$ & $2 \cdot 65 \pm 0.13^{*}$ & 363 \\
\hline 0 & $17 \cdot 6 \pm 2 \cdot 1$ & $28 \cdot 7 \pm 2 \cdot 0$ & $32 \cdot 6 \pm 1 \cdot 3$ & $21 \cdot 0 \pm 3 \cdot 2$ & $2.57 \pm 0.09^{*}$ & 359 \\
\hline 0 & $15 \cdot 4 \pm 2 \cdot 1$ & $25 \cdot 9 \pm 2 \cdot 0$ & $35 \cdot 7 \pm 2 \cdot 3$ & $23 \cdot 0 \pm 3 \cdot 5$ & $2 \cdot 66 \pm 0.12^{\star}$ & 336 \\
\hline $4 \cdot 7 \pm 2 \cdot 8$ & $21 \cdot 3 \pm 3 \cdot 5$ & $30 \cdot 5 \pm 3 \cdot 1$ & $28 \cdot 1 \pm 3 \cdot 2$ & $15 \cdot 8 \pm 3 \cdot 6$ & $2 \cdot 29 \pm 0.14$ & 374 \\
\hline
\end{tabular}

aPercentages (means \pm S.E.M. for four replicates) were based on CEOs used for maturation. *Significantly lower $(P<0.05)$ than control value in the FSH absence treatment and ${ }^{*}$ significantly lower $(P<0.01)$ than control value in the $\mathrm{FSH}$ presence treatment.

${ }^{b} \mathrm{CEI}$, cumulus expansion index. This represents the mean expansion value for the complexes, with 0 equal to no expansion, and 4 equal to maximal expansion. 

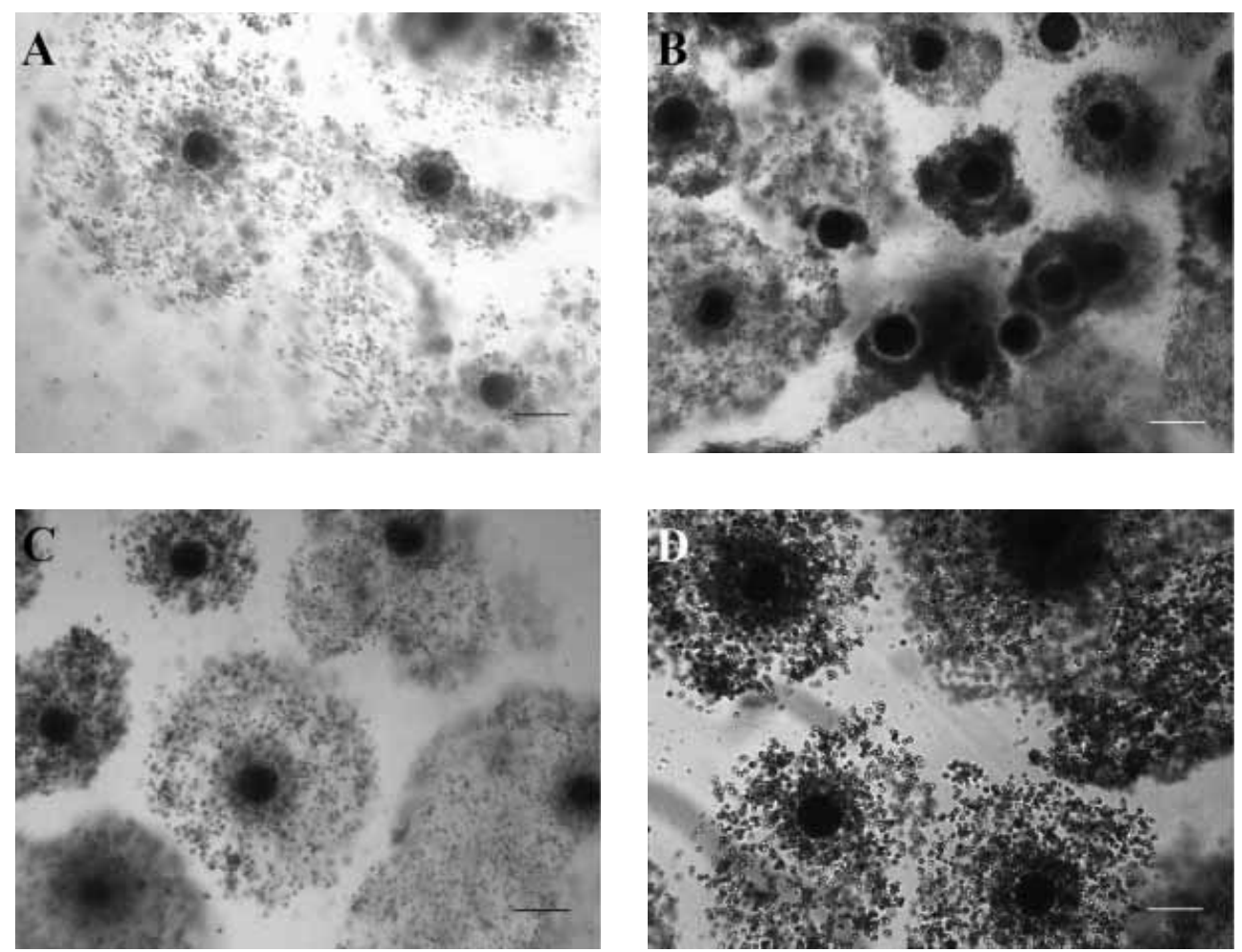

Figure 6 Photomicrographs of pig cumulus expansion. Pig CEOs were cultured in maturation medium containing different drugs for $44 \mathrm{~h}$. (A) FSH treatment showed a maximal degree of cumulus expansion. (B) Control treatment without any drug showed an obviously lower degree of cumulus expansion. (C) FSH+ANP treatment and (D) forskolin treatment showed a similar degree of cumulus expansion. Bars $=150 \mu \mathrm{m}$.

cAMP phosphodiesterase (Sandberg et al. 1993), but inhibits spontaneous rat oocyte maturation by cGMP accumulation (Törnell et al. 1990). However, suppression of MAPK activation in Xenopus oocytes does not inhibit progesterone-induced GVBD, suggesting that the activation of MAPK is actually not necessary for the resumption of meiosis, and therefore, an alternative pathway may exist in frog oocytes for triggering the resumption of meiosis (Fisher et al. 1999). Similarly, different pathways may also exist in rat oocytes, since FSH has no obvious function in rat oocyte maturation in vitro (Zhang \& Armstrong 1989).

A drop in intracellular cAMP levels followed by the decrease of the cAMP-dependent protein kinase (PKA) activity is associated with oocyte resumption of meiosis (Sun et al. 1999). Forskolin, stimulating adenylyl cyclase by a combination of direct interaction with adenylyl cyclase and activation of Gs protein (for review see Taussig \& Gilman 1995), strongly induces the cAMP content of CEOs and DOs in a dose-dependent manner (Racowsky 1985), and inhibits the meiotic resumption and MAPK activation (Sun et al. 1999). In this study, treatment with forskolin for $44 \mathrm{~h}$ strongly inhibited the meiotic maturation of both CEOs and DOs. However, both ANP and C-ANP-(4-23) did not completely inhibit the action of forskolin $(44 \mathrm{~h})$ in the maturation of pig CEOs, suggesting that the inhibitory effect of ANP/ C-ANP-(4-23) is not sufficient to alter the functional responses induced by forskolin. ANP seems to 'attenuate' the action of forskolin, consistent with previous results that the cAMP levels stimulated by forskolin in guinea pig tracheal smooth muscle could only be partially blocked by ANP (Devillier et al. 2001). The attenuated effect of ANP and C-ANP-(4-23) on forskolin was completely eliminated by pretreatment with PT, suggesting that this effect is therefore probably related to adenylyl cyclase inhibition by the activation of the PT-sensitive Gi protein(s) (Panchenko et al. 1998).

It is generally accepted that increased cAMP in oocytes maintains them in the meiotic arrest stage, but increased cAMP in the intra-cumulus cells plays an important role in controlling oocyte maturation. When activated by FSH, MAPK may stimulate the synthesis of specific proteins and then the secretion of a uncharacterized factor(s) of somatic cell origin $(\mathrm{Su}$ et al. 1999), for example follicular fluid meiosis-activating sterol (FF-MAS) secreted by follicular somatic cells in response to gonadotrophic stimulation (Byskov et al. 
1997, Thomas et al. 2002, Xie et al. 2004). The secretion of FF-MAS by granulosa cells is itself a cAMPdependent process. Forskolin can mimic the effect of gonadotrophin on oocyte maturation by short-term priming (Xia et al. 2000, Lu et al. 2001). Treatment with forskolin for $2 \mathrm{~h}$ induced pig GEOs but inhibited DO spontaneous maturation in our study. These different effects of forskolin on progression of meiosis in CEOs and DOs may be consistent with a role of factor(s) secreted by cumulus cells in response to high levels of cAMP that override the meiosis-inhibiting action of cAMP on completion of meiosis (Byskov et al. 1995, 1997). Similarly, ANP and C-ANP-(4-23) could inhibit the effect of forskolin on the maturation of pig CEOs, and pretreatment with PT could eliminate this inhibitory effect. These results further suggest that ANP has a regulatory effect on forskolin-mediated oocyte maturation via the PT-sensitive Gi protein(s).

It has been reported that the cumulus cell, not the oocyte itself, has ANP receptors and guanylate cyclases in the rat (Törnell et al. 1990). Here we have no evidence suggesting whether the NPRA or the NPRB receptor mediates the effect on FSH-induced oocyte maturation. ANP shows high affinity for NPRA receptors (for review see Takei 2000), and the concentrations of ANP used in this study were in the same range as those used to regulate MAPK phosphorylation by the ANP/NPRA system (Pandey et al. 2000), suggesting that the inhibitory effect of ANP on FSH-induced pig oocyte maturation is more likely involving the specific receptor NPRA.

As both ANP and C-ANP-(4-23) could block the function of forskolin on CEO maturation, the present results provide evidence that NPRG receptors are functional in pig cumulus cells as in other cells (Devillier et al. 2001), but the oocyte lacks NPRG receptors mediating the attenuation. In spite of binding to NPRC receptors, ANP may also bind to NPRA receptors to promote the accumulation of cGMP (Panchenko et al. 1998). The possible accumulation of cGMP induced by ANP was apparently ineffective in forskolin-mediated oocyte maturation in our study, since PT pretreatment to block the NPRG-Gi protein(s) pathway could completely reverse the effect of ANP on the action of forskolin. However, the forskolin-induced cAMP pathway may block GVBD by inhibiting maturation promoting factor activation rather than inhibiting MAPK phosphorylation, since MAPK activation is not the prerequisite of spontaneous meiotic maturation in mammalian oocytes (Su et al. 2002, Fan et al. 2003). Alternatively, ANP should not affect the FSH-induced maturation of pig CEOs via binding to NPRC receptors, since the inhibitory effect of ANP was completely reversed by KT5823, and C-ANP-(4-23) was ineffective in FSH-induced oocyte maturation. It seems that ANP could produce physiological actions in the ovary via two different signal pathways: one is to induce cGMP accumulation via NPRA (or NPRB) receptors, and the other is to inhibit adenylyl cyclase in a PTsensitive manner via NPRC receptors as in other tissue (Anand-Srivastava et al. 1996).

It is puzzling that ANP inhibits FSH-induced oocyte maturation via the PKG pathway, but inhibits the action of forskolin on oocyte maturation via NPRG receptors and PT-sensitive Gi protein(s), in spite of the fact that both FSH and forskolin affect oocyte maturation primarily via the activation of the PKA pathway (Racowsky 1985, Conti \& Jin 1999). Gonadotrophin receptors may be coupled to other heterotrimeric G proteins (such as $\mathrm{Gq}$ protein), except in the cAMP signalling pathway (for review see Conti 2002), but we showed that anti-Gq $\alpha \quad\left(G_{11} \alpha\right)$ had no effect on FSH-induced pig CEO maturation (data not shown). Studies on endocrine and non-endocrine cells have shown that cAMP-phosphodiesterases 4 (cAMP-PDE4s) expression in granulosa and theca cells but not in oocytes (Tsafriri et al. 1996), are part of a feedback control of cAMP levels stimulated by gonadotrophin (for review see Conti 2000). Stimulation of cultured rat granulosa cells with FSH causes a significant increase in PDE4s activity, which may in turn decrease the cAMP levels (Conti et al. 1984). FSH, forskolin or db-cAMP significantly increases activin $\beta \mathrm{A}$ expression while suppressing the expression of activin $\beta \mathrm{B}$, but no significant desensitization is noticed for forskolin and db-cAMP over the concentration ranges tested (Wang \& Ge 2003). Furthermore, a portion of the cAMP generated in response to forskolin is formed in a functional compartment that lacks access to cAMPdependent protein kinase (Zhou et al. 1992). From the discussion above, we postulate that ANP may not be sensitive to the relatively low cAMP levels stimulated by FSH because of the feedback control by PDE4s, but obviously inhibits the increase of MAPK phosphorylation via the PKG pathway. On the contrary, ANP may be sensitive to the large increase in cAMP content stimulated by forskolin and directly induce the inhibitory effect on forskolin via NPRC receptors and PT-sensitive Gi protein(s). Does ANP moderately modulate the actions of FSH and forskolin on pig oocyte maturation via different signalling pathways in order to prevent the intense physiological reaction? Its further regulation mechanism remains to be elucidated. Compared with FSH, treatment with forskolin for $44 \mathrm{~h}$ exhibited a relatively low sensitivity to ANP and C-ANP-(4-23), since this diterpene rapidly stimulates the catalytic subunit of adenylate cyclase (Seamon \& Daly 1981) and generates a large enough increase in cAMP content to elicit an optimal activation of cAMP-dependent protein kinase (Devillier et al. 2001).

Cumulus expansion induced by gonadotrophin requires the participation of MAPK (Su et al. 2002). Inhibition of MAPK activation prevents gonadotrophinstimulated resumption of meiosis as well as cumulus 
expansion (Su et al. 2003). In our study, the inhibitory effect of ANP on FSH-induced cumulus expansion might be via the inhibition of MAPK phosphorylation, since FSH-induced MAPK phosphorylation was obviously inhibited by ANP in both oocytes and cumulus cells. However, forskolin-induced cumulus expansion was not inhibited in the presence of ANP or C-ANP-(4-23). The possible explanations are that forskolin generated a large enough increase in cAMP content to induce cumulus expansion in spite of the presence of ANP or C-ANP-(4-23).

The fact that treatment with forskolin for $44 \mathrm{~h}$ induced cumulus expansion but inhibited pig CEO maturation, while treatment with forskolin for $2 \mathrm{~h}$ only induced CEO maturation, supports the previous conclusions of Eppig (1979) and Racowsky (1985) that oocyte maturation is not a prerequisite for cumulus expansion. In the mouse, cumulus expansion induced by FSH is dependent upon specific cumulus-expansionenabling factor(s) secreted by the oocyte (Buccione $e t$ al. 1990, Salustri et al. 1990), but in the pig, cumulus expansion induced by FSH or forskolin is not dependent on the oocyte (Procházka et al. 1991). However, compared with the almost full expansion induced by FSH, the extent of expansion stimulated by forskolin is limited to the outer layers of the cumulus cells as in our and other studies (Racowsky 1985, Procházka et al. 1991), suggesting that the normal interaction between oocytes and cumulus cells in the pig may be needed for the full cumulus expansion.

In conclusion, ANP inhibits the actions of FSH and forskolin on pig oocyte maturation via different receptors and signalling pathways. One is via the cGMP/PKG pathway, and the other is via NPRC receptors in cumulus cells and the activation of PT-sensitive Gi protein(s). ANP alone is ineffective in oocyte maturation cultured in drug-free medium. These results suggest that the diverse responses of ANP could mediate the action of cAMP via different signalling pathways during pig follicular development.

\section{Acknowledgements}

This research was supported by grants from the National Outstanding Youth Foundation of China (No. 30025032) and Beijing Natural Science Foundation (No. 6992019). The authors declare that there is no conflict of interest that would prejudice the impariality of this research.

\section{References}

Anand-Srivastava MB, Sehl PD \& Lowe DG 1996 Cytoplasmic domain of natriuretic peptide receptor-C inhibits adenylyl cyclase. Fournal of Biological Chemistry 271 19324-19329.
Anderson RA, Feathergill KA, Drisdel RC, Rawlins RG, Mack SR \& Zaneveld LJ 1994 Atrial natriuretic peptide (ANP) as a stimulus of the human acrosome reaction and a component of ovarian follicular fluid: correlation of follicular ANP content with in vitro fertilization outcome. Foumal of Andrology 15 61-70.

Bovy PR, O'Neal JM, Olins GM \& Patton DR 1989 Identification of structural requirements for analogues of atrial natriuretic peptide (ANP) to discriminate between ANP receptor subtypes. Fournal of Medicinal Chemistry 32 869-874.

Buccione R, Vanderhyden BC, Caron PJ \& Eppig JJ 1990 $\mathrm{FSH}$-induced expansion of the mouse cumulus oophorus in vitro is dependent upon a specific factor(s) secreted by the oocyte. Developmental Biology 138 16-25.

Byskov AG, Andersen CY, Nordholm L, Thogersen H, Xia GL, Wassmann O, Andersen JV, Guddal E \& Roed T 1995 Chemical structure of sterols that activate oocyte meiosis. Nature 374 559-562.

Byskov AG, Yding Andersen C, Hossaini A \& Guoliang X 1997 Cumulus cells of oocyte-cumulus complexes secrete a meiosis-activating substance when stimulated with FSH. Molecular Reproduction and Development 46 296-305.

Cameron MR, Foster JS, Bukovsky A \& Wimalasena J 1996 Activation of mitogen-activated protein kinases by gonadotropins and cyclic adenosine $5^{\prime}$-monophosphates in porcine granulosa cells. Biology of Reproduction 55 111-119.

Conti M 2000 Phosphodiesterases and cyclic nucleotide signalling in endocrine cells. Molecular Endocrinology 14 1317-1327.

Conti M 2002 Specificity of the cyclic adenosine $3^{\prime}, 5^{\prime}$-monophosphate signal in granulosa cell function. Biology of Reproduction $\mathbf{6 7}$ 1653-1661.

Conti M \& Jin SL 1999 The molecular biology of cyclic nucleotide phosphodiesterases. Progress in Nucleic Acid Research and Molecular Biology 63 1-38.

Conti M, Kasson BG \& Hsueh AJ 1984 Hormonal regulation of $3^{\prime}, 5^{\prime}$-adenosine monophosphate phosphodiesterases in cultured rat granulosa cells. Endocrinology $1142361-2368$.

De Bold AJ, Kuroski-De Bold ML, Boer PH, Dubé G, Mangat H \& Johnson F 1991 A decade of atrial natriuretic factor research. Canadian Fournal of Physiology and Pharmacology 69 1480-1485.

Dekel N, Aberdam E \& Sherizly I 1984 Spontaneous maturation in vitro of cumulus-enclosed rat oocytes is inhibited by forskolin. Biology of Reproduction 31 244-250.

Devillier P, Corompt E, Breant D, Caron F \& Bessard G 2001 Relaxation and modulation of cyclic AMP production in guinea pig tracheal smooth muscle. European Fournal of Pharmacology $\mathbf{4 3 0}$ 325-333.

Downs SM 1989 Specificity of epidermal growth factor action on maturation of the murine oocyte and cumulus oophorus in vitro. Biology of Reproduction 41 371-379.

Drewett JG, Ziegler RJ \& Trachte GJ 1992 Neuromodulatory effects of atrial natriuretic peptides correlate with an inhibition of adenylate cyclase but not an activation of guanylate cyclase. Fournal of Pharmacology and Experimental Therapeutics $260689-696$.

Eppig JJ 1979 Gonadotropin stimulation of the expansion of cumulus oophori isolated from mice: general conditions for expansion in vitro. Fournal of Experimental Zoology 208 111-120.

Eppig JJ 1993 Regulation of mammalian oocyte maturation. In The Ovary, pp 185-208. Eds EY Adashi \& PCK Leung. New York: Raven Press.

Fagbohun CF \& Downs SM 1990 Maturation of the mouse oocyte-cumulus cell complex: stimulation by lectins. Biology of Reproduction 42 413-423.

Fan HY, Tong C, Lian L, Li SW, Gao WX, Cheng Y, Chen DY, Schatten H \& Sun QY 2003 Characterization of ribosomal S6 protein kinase p90 rsk during meiotic maturation and fertilization in pig oocytes: mitogen-activated protein kinase-associated activation and localization. Biology of Reproduction 68 968-977. 
Fisher DL, Brassac T, Galas S \& Doree M 1999 Dissociation of MAP kinase activation and MPF activation in hormone-stimulated maturation of Xenopus oocytes. Development 126 4537-4546.

Flynn TG, de Bold ML \& de Bold AJ 1983 The amino acid sequence of an atrial peptide with potent diuretic and natriuretic properties. Biochemical and Biophysical Research Communications 117 859-863.

Funahashi H, Cantley TC \& Day BN 1994 Different hormonal requirement of pig oocyte-cumulus complexes during maturation in vitro. Fournal of Reproduction and Fertility 101 159-165.

Gerbes AL, Dagnino L, Nguyen T \& Nemer MT 1994 Transcription of brain natriuretic peptide and atrial natriuretic peptide genes in human tissues. Fournal of Clinical Endocrinology and Metabolism 78 1307-1311.

Gutkowska J, Tremblay J, Antakly T, Meyer R, Mukaddam-Daher S \& Nemer M 1993 The atrial natriuretic peptide system in rat ovaries. Endocrinology 132 693-700.

Gutkowska J, Jankowski M, Sairam MR, Fujio N, Reis AM, Mukaddam-Daher S \& Tremblay J 1999 Hormonal regulation of natriuretic peptide system during induced ovarian follicular development in the rat. Biology of Reproduction 61 162-170.

Homa ST 1988 Effects of cyclic AMP on the spontaneous meiotic maturation of cumulus-free bovine oocytes cultured in chemically defined medium. Fournal of Experimental Zoology $\mathbf{2 4 8}$ 222-231.

Hubbard CJ \& Price J 1988 The effects of follicle-stimulating hormone and cyclic guanosine $3^{\prime}, 5^{\prime}$-monophosphate on cyclic adenosine $3^{\prime}, 5^{\prime}$-monophosphate-phosphodiesterase and resumption of meiosis in hamster cumulus-oocyte complexes. Biology of Reproduction 39 829-838.

Ivanova MD, Gregoraszczuk EL, Augustowska K, Kolodziejczyk J, Mollova MV \& Kehayov IR 2003 Localization of atrial natriuretic peptide in pig granulosa cells isolated from ovarian follicles of various size. Reproductive Biology 3 173-181.

Johnson KM, Hughes FM Jr, Fong YY, Mathur RS, Williamson HO \& Gorospe WC 1994 Effects of atrial natriuretic peptide on rat ovarian granulosa cell steroidogenesis in vitro. American fournal of Reproductive Immunology 31 163-168.

Kim SH, Cho KW, Lim SH, Hwang YH, Ryu H, Oh SH, Seul KH, Jeong GB \& Yoon S 1992 Presence and release of immunoreactive atrial natriuretic peptide in granulosa cells of the pig ovarian follicle. Regulatory Peptides 42 153-162.

Kim SH, Cho KW, Oh SH, Hwang YH, Lim SH, Ryu H, Seul KH, Jeong GB \& Yoon S 1993 Immunoreactive atrial natriuretic peptides in the oocyte. Comparative Biochemistry and Physiology: Comparative Physiology 104 219-223.

Kim SH, Cho KW, Kim SZ \& Koh GY 1997 Characterization of the atrial natriuretic peptide system in the oviduct. Endocrinology $1382410-2416$

Kim SJ, Shinjo M, Usuki S, Tada M, Miyazaki H \& Murakami K 1987 Binding sites for atrial natriuretic peptide in high concentration in human ovaries. Biomedicine Research 8 415-420.

Konrad EM, Thibault G, Schiffrin EL \& Cantin M 1991 Atrial natriuretic factor receptor subtypes in the rat central nervous system. Hypertension 17 1144-1151.

La Polt PS, Leung K, Ishimaru R, Tafoya MA \& Chen JY 2002 Roles of cyclic GMP in modulating ovarian functions. Reproductive Biomedicine 6 15-23.

Lu ZX, Xia GL \& Zhang JC 2001 Protein kinase C, rather than protein kinase A is involved in follicle-stimulating hormone-mediated meiotic resumption of mouse cumulus cell-enclosed oocytes in hypoxanthine-supplemented medium. Molecular and Cellular Endocrinology 182 225-232.

Maack T 1992 Receptors of atrial natriuretic factor. Annual Review of Biochemistry 54 11-27.

Maack T, Suzuki M, Almeida FA, Nussenzveig D, Scarborough RM, McEnroe GA \& Lewicki JA 1987 Physiological role of silent receptors of atrial natriuretic factor. Science 238 675-678.
Olsiewski PJ \& Beer WH 1983 cAMP synthesis in rat oocyte. Developmental Biology 100 287-293.

Panchenko MP, Joyce-Brady M, Starikova MG, Oakes SM, Adachi R, Brody JS \& Dickey BF 1998 Atrial natriuretic peptide modulates alveolar type 2 cell adenylyl and guanylyl cyclases and inhibits surfactant secretion. Biochimica et Biophysica Acta 1403 115-125.

Pandey KN, Nguyen HT, Li M \& Boyle JW 2000 Natriuretic peptide receptor-A negatively regulates mitogen-activated protein kinase and proliferation of mesangial cells: role of cGMP-dependent protein kinase. Biochemical and Biophysical Research Communications 271 374-379.

Procházka R, Nagyová E, Rimkevicová Z, Nagai T, Kikuchi K \& Motlík J 1991 Lack of effect of oocytectomy on expansion of the porcine cumulus. Fournal of Reproduction and Fertility $\mathbf{9 3}$ 569-576.

Racowsky C 1985 Effect of forskolin on maintenance of meiotic arrest and stimulation of cumulus expansion, progesterone and cyclic AMP production by pig oocyte-cumulus complexes. Fournal of Reproduction and Fertility $\mathbf{7 4}$ 9-21.

Rosenzweig A \& Seidman CE 1991 Atrial natriuretic factor and related peptide hormones. Annual Review of Biochemistry 60 229-255.

Russinova A, Mourdjeva M, Kyurkchiev S \& Kehayov I 2001 Immunohistochemical detection of atrial natriuretic factor (ANF) in different ovarian cell types. Endocrine Regulations 35 81-89.

Saheki T, Shimonaka M, Uchida K, Mizunno T \& Hirose S 1989 Immunochemical and biochemical distinction of subtypes of atrial natriuretic peptide receptor. Fournal of Biochemistry 106 627-632.

Salustri A, Yanagishita M \& Hascall VC 1990 Mouse oocytes regulate hyaluronic acid synthesis and mucification by FSH-stimulated cumulus cells. Developmental Biology 138 26-32.

Sandberg K, Bor M, Ji H, Carvallo PM \& Catt KJ 1993 Atrial natriuretic factor activates cyclic adenosine $3^{\prime}, 5^{\prime}$-monophosphate phosphodiesterase in Xenopus laevis oocytes and potentiates progesterone-induced maturation via cyclic guanosine 5'-monophosphate accumulation. Biology of Reproduction $\mathbf{4 9}$ $1074-1082$.

Seamon KB \& Daly JW 1981 Forskolin: a unique diterpene activator of cAMP generating systems. Fournal of Cyclic Nucleotide Research 7 201-224.

Sirard MA 1990 Temporary inhibition of meiosis resumption in vitro by adenylate cyclase stimulation in immature bovine oocytes. Theriogenology 33 757-767.

Steegers EA, Hollanders JM, Jongsma HW \& Hein PR 1990 Atrial natriuretic peptide and progesterone in ovarian follicular fluid. Gynecologic and Obstetric Investigation 29 185-187.

Su YQ Xia GL, Byskov AG, Fu CD \& Yang CR 1999 Protein kinase $\mathrm{C}$ and intracellular calcium are involved in follicle-stimulating hormone-mediated meiotic resumption of cumulus cell-enclosed porcine oocytes in hypoxanthine-supplemented medium. Molecular Reproduction and Development $\mathbf{5 3}$ 51-58.

Su YQ, Wigglesworth K, Pendola FL, O’ Brien MJ \& Eppig.JJ 2002 Mitogen-activated protein kinase activity in cumulus cells is essential for gonadotropin-induced oocyte meiotic resumption and cumulus expansion in the mouse. Endocrinology 143 2221-2232.

Su YQ, Denegre JM, Wigglesworth K, Pendola FL, O'Brien MJ \& Eppig JJ 2003 Oocyte-dependent activation of mitogen-activated protein kinase (ERK1/2) in cumulus cells is required for the maturation of the mouse oocyte-cumulus cell complex. Developmental Biology 263 126-138.

Sun QY, Breitbart H \& Schatten H 1999 Role of the MAPK cascade in mammalian germ cells. Reproduction, Fertility, and Development $11443-450$.

Takei Y 2000 Structural and functional evolution of the natriuretic peptide system in vertebrates. International Review of Cytology 194 $1-66$. 
Takei Y 2001 Does the natriuretic peptide system exist throughout the animal and plant kingdom. Comparative Biochemistry and Physiology Part B: Biochemistry and Molecular Biology 129 559-573.

Tatemoto H, Okuda T, Sogo N \& Muto N 2001 Male pronuclear formation and blastocyst formation are improved by supplementation of ascorbic acid 2-O- $\alpha$-glucoside during in vitro maturation culture of denuded porcine oocytes. Fournal of Reproduction and Development 47 329-339.

Taussig R \& Gilman AG 1995 Mammalian membrane-bound adenylyl cyclases. Fournal of Biological Chemistry $2701-4$.

Thomas RE, Armstrong DT \& Gilchrist RB 2002 Differential effects of specific phosphodiesterase isoenzyme inhibitors on bovine oocyte meiotic maturation. Developmental Biology 244 215-225.

Törnell J, Carlsson B \& Billig H 1990 Atrial natriuretic peptide inhibits spontaneous rat oocyte maturation. Endocrinology 126 1504-1508.

Tsafriri A, Chun SY, Zhang R, Hsueh AJ \& Conti M 1996 Oocyte maturation involves compartmentalization and opposing changes of cAMP levels in follicular somatic and germ cells: studies using selective phosphodiesterase inhibitors. Developmental Biology 178 393-402.

Usuki S, Saitoh T, Saitoh M, Tanaka J, Kawakura Y, Usuki Y, Shinjo M \& Kim SJ 1993 Endothelin-renin-angiotensin-atrial natriuretic peptide system in ovaries: an intraovarian ERAANP system. Fournal of Cardiovascular Pharmacology 22 207-210.

Vanderhyden BC 1993 Species differences in the regulation of cumulus expansion by an oocyte-secreted factor(s). Foumal of Reproduction and Fertility 98 219-227.

Vollmar AM, Mytzka C, Arendt RM \& Schulz R 1988 Atrial natriuretic peptide in bovine corpus luteum. Endocrinology 123 $762-767$.
Wang YJ \& Ge W 2003 Involvement of cyclic adenosine $3^{\prime}, 5^{\prime}$-monophosphate in the differential regulation of activin $\beta \mathrm{A}$ and $\beta \mathrm{B}$ expression by gonadotropin in the zebrafish ovarian follicle cells. Endocrinology 144 491-499.

Xia GL, Byskov AG \& Andersen YC 1994 Cumulus cells secrete a meiosis-inducing substance by stimulation with forskolin and dibutyric cyclic adenosine monophosphate. Molecular Reproduction and Development 39 17-24.

Xia GL, Kikuchi K, Noguchi J \& Izaike Y 2000 Short time priming of pig cumulus-oocyte complexes with FSH and forskolin in the presence of hypoxanthine stimulates cumulus cells to secrete a meiosis-activating substance. Theriogenology 53 $1807-1815$

Xie H, Xia G, Byskov AG, Andersen CY, Bo S \& Tao Y 2004 Roles of gonadotropins and meiosis-activating sterols in meiotic resumption of cultured follicle-enclosed mouse oocytes. Molecular and Cellular Endocrinology 218 155-163.

Zhang X \& Armstrong DT 1989 Effects of follicle-stimulating hormone and ovarian steroids during in vitro meiotic maturation on fertilization of rat oocytes. Gamete Research $\mathbf{2 3}$ 267-277.

Zhou HL, Newsholme SJ \& Torphy TJ 1992 Agonist-related differences in the relationship between cAMP content and protein kinase activity in canine trachealis. Fournal of Pharmacology and Experiment Therapeutics 261 1260-1267.

Received 12 October 2004

Accepted 27 November 2004

Made available online as an Accepted Preprint

7 December 2004 